\title{
Obesity Leads to Elevated Level of Circulating Cell-Free DNA
} \author{
and Atif $\mathrm{AB}^{1 *}$ \\ ${ }^{1}$ Faculty of Medicine, Universiti Sultan Zainal Abidin, Kuala Terengganu, Malaysia \\ ${ }^{2}$ Institute for Community (Health) Development, Universiti Sultan ZainalAbidin, Malaysia \\ ${ }^{3}$ Department of Chemical Pathology, CMH Quetta, Pakistan
}

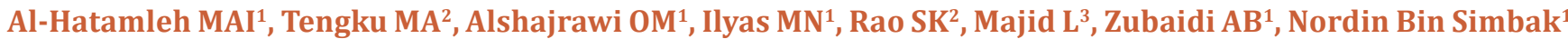

Submission: June 06, 2018; Published: September 20, 2018

*Corresponding author: Atif Amin Baig, Faculty of Medicine, Universiti Sultan Zainal Abidin, Kuala Terengganu, Malaysia, Tel: +601121673046

, Email: atifamin@unisza.edu.my

\begin{abstract}
With the steadily growing number of studies in the issues related to obesity research, it is proven, that obesity might be related to wide number of body disorders, some of these disorders have been already studied and investigated, and some still needed more investigations, which has opened new horizons to unlimite hypotheses about involvement of obesity in many physiological disorders. In the current opinion, we hypothesized to the conclusion that there is a correlation between obesity severity and elevated cfDNA levels in the circulation. This correlation is based on free radicals and oxidative stress hypothesis of cellular and molecular damage in cell injury, which in turn leads to a disorder in the whole body and enhances the inflammatory status.
\end{abstract}

Keywords: Obesity; Inflammation; Oxidative stress; Free radicals; Cfdna

Abbrevations: WHO: World Health Organization; NIH: National Institutes of Health; BMI: Body Mass Index; LEPR: Leptin Receptor; LEP: Leptin; POMC: Pro-Opiomelanocortin; MC4R: Melanocortin-4 Receptor; SNP: Single-Nucleotide Polymorphisms; ROS: Reactive Oxygen Species

\section{Introduction}

It is clear to the medical community the importance and impact of the various types of obesity on a wide range of diseases and physical disorders and requires more research and investigation in any relationship suspected between obesity and other disorders. This review emphasizes a new opinion and summarises the current state of knowledge about the impact of obesity on level of cell-free DNA in circulation, which has been used recently as a new and significant biomarker for some illness and inflammatory disorders.

Obesity has received significant attention as a complex health hazard. Obesity is defined as a status of excessive fat accumulation in adipose tissue which is resulting in health is impairment [1]. The National Institutes of health (NIH) and The World Health Organization (WHO) have used Body Mass Index (BMI) which is the most widely used measure of obesity due to its low cost and simplicity. BMI is defined as the weight in kilograms divided by the height in meters squared, according to BMI overweight means as a BMI between 25.0 and $29.9 \mathrm{~kg} / \mathrm{m} 2$; and obesity as a BMI greater than $30.0 \mathrm{~kg} / \mathrm{m} 2$ [2,3].

The most common methods used as reference measures of body composition especially for research purposes include single-cut imaging of the abdomen using computed tomography scan or magnetic resonance imaging, densitometry, and dual- energy X-ray absorptiometry. However, increasing evidence indicates that abdominal obesity is also useful beside total body fat, and it is independent predictor of several cancer and cardiovascular-related outcomes in addition to other illnesses [3]. Some of the commonly used measures of abdominal obesity are hip circumference, waist circumference, and waist-to-hip ratio $[2,3]$.

\section{Prevalence of Obesity}

Obesity is a complex, multifactorial, and one of the greatest public health epidemics of the 21st century [4]. The prevalence of obesity is rising globally, with about 2 billion adults worldwide currently classified as being overweight or obese [5]. However, estimates of its prevalence are still insufficient for all countries, and the available data are not comparable or uniformly accurate [6]. If secular trends continue, by 2030 an estimated $20 \%$ will be obese and another $38 \%$ of the world's adult population will be overweight [7]. In the USA, based on earlier secular trends point, by 2030 an estimated $85 \%$ of adults will be obese or overweight [8]. Whereas in most developed countries growth, trends in overall obesity seem to have levelled off [9], but still morbid obesity in many of these countries continues to rise, including among children. Furthermore, obesity prevalence in most developing countries continues to trend upwards toward US levels [8]. 


\section{Common Causes of Obesity}

Environmental factors are seeming to be major contributors to the obesity. It is certain that obesity evolves when there is an imbalance between increase energy intake and decrease energy expenditure. Evidence supports the contribution of both excess energy intake and decreased energy expenditure in the obesity epidemic [10-12]. On the other hand, it is known that single gene mutations are associate with rare forms of monogenic obesity (leptin receptor (LEPR), leptin (LEP), pro-opiomelanocortin (POMC), and melanocortin-4 receptor (MC4R)) [13]. However, there is growing evidence that singlenucleotide polymorphisms (SNP) or common genetic variants may play an important role in the obesity. These SNPs have some effects on an individual susceptibility to obesity, but due to their high frequencies, if involved in lipogenic pathways, may be able to have a wide contribution to obesity in the population [14]. Besides, nutrigentics plays a vital role [15]. The methods used for analysis these mutations are limited and there is a need to work with a cos-effective method [16,17] and to consider any particular method as a prominent bimolecular tool for obesity and its severity.

\section{Obesity and Oxidative Stress}

It has been reported that obesity is associated with chronic systemic inflammation in adipose tissue. This condition is affected by the activation of the innate immune system in adipose tissue that enhances oxidative stress and pro-inflammatory status, affecting a systemic acute-phase response. Various chronic diseases are also the result of obesity (e.g., diabetes mellitus, metabolic syndrome, cancers, and cardiovascular and liver diseases) and associated with oxidative stress [18]. So, it has been hypothesized that inflammation of adipose tissue in obese patients plays a significant role in the pathogenesis of obesity-related disorders [19].

Adipose tissue is a storage organ required for energy homeostasis. Adipose tissue is composed of adipocytes primarily and contains other cells (e.g. pre-adipocytes, endothelial, fibroblasts, fibroblastic and immune cells) [20], secreting hormones and cytokines (adipocytokines or adipokines) which exercise autocrine, endocrine, and paracrine action on the whole body. In pathological and, even more, in physiological conditions, adipokines also induce the production of reactive oxygen species (ROS), generating oxidative stress and, in turn, a major, irregular output of other adipokines [21]. Oxidative stress and pro-inflammatory processes are strongly associated $[22,23]$. Upon activation, many immune cells produce free radicals, and, in the same way, the synthesis of ROS enhances the inflammatory status.

\section{Oxidative Stress and Cell Aging}

Oxidative stress is also considered as a measure of unbalance between the production of free radicals and antioxidant defences [24-26]. Oxidative stress has been involved in response to stress and the pathogenesis of psychiatric and neurologic diseases [27-29]. Mostly, the main cause of oxidative stress has been a production of free radicals. Free radicals are chemical species which contain an odd number of electrons in last electronic layer [30]. This state of electrons of the last layer that grant high reactivity to these molecules or atoms [31]. ROS often generated by mitochondria, in addition to other sources of ROS, such as NADPH oxidase (NOX) enzymes; they are a group of membrane proteins with a known function to generate ROS. These enzymes are working as a transmembrane electron transport chain by using cytoplasmic NADPH as an electron granter to 02 molecule to generate superoxide anion in the lumen of intracellular organelles or the extracellular space. Superoxide anion is mostly considered the essential product of the electron transfer, also to generate other ROS in particular hydrogen peroxide [32,33].

The researchers have identified a total of seven NOX genes: NOX1 to 5 and DUOX1 and 2. The better-described isoform NOX2 needs interaction with another trans-membrane protein, p22phox, in addition to the cytosolic subunits, p40phox, p47phox, p67phox, and with one of the small Rho GTP-binding proteins, Rac1 or 2. On the other hand, other NOX isoforms have a different mechanism of activation and require p22phox for activity. NOX3 and NOX1 enzymes require interaction with cytosolic subunits, NOXO1 and NOXA1, and with Rac1 or 2 [34]. NOX 4 seems to be constitutively active; NOX5 and DUOX enzymes are often regulated by increased intracellular Ca2+ [33]. It is worth mentioning that ROS generated by NOX enzymes can directly impact cellular functions; by encourage the oxidation of proteins, then their functional and structural changes [13]. From this particular issue we suggested that increases oxidative stress which is enhances the inflammatory status, subsequently causes damage and destruction of cells which is increasing cell-free DNA in circulation.

\section{Circulating Cell-Free DNA}

In 1948, Mandel and Metais discovered the presence of cellfree DNA (cfDNA) in blood plasma [35]. This discovery was not attracted great attention in the medical scientific community until 1994; when the importance of cfDNA was explored in the study of mutated RAS gene fragments in the circulation of cancer patients [36,37]. Understanding the mechanisms of generation of cfDNA is important for conclusion its role in pathology and biology and speeding the translation of analyses to clinical practice. Despite the apparent of cfDNA in blood circulation and other bio-fluids, the exposition of its origin has only been a partial triumph [36,37].

Mostly, cfDNA are found as double-stranded molecules with molecular weights in the wide range of $0.18 \mathrm{kB}$ to $21 \mathrm{kB}[38,39]$. Various possible sources and cognate mechanisms have been detected. Firstly, it was supposed that cfDNA enters the blood following the cells lysis on the interface between a tumour and blood circulation only. Since it was reported in patients that the concentration of cfDNA in their blood is higher than could be 
accounted for by the mass of cells present, this hypothesis has been abandoned [40]. The exact mechanism of releasing cfDNA into the blood circulation is still unknown, several researchers have suggested that in either healthy or diseased individual's cfDNA is predominantly haematopoietic origin [41,42]. They also demonstrated that under normal conditions, cfDNA is released from apoptotic rather than necrotic processes. It should be emphasized on the role of a dynamic balance between processes of cellular DNA secretion/release and mechanisms of DNA degradation and clearance in the keep of the existing level of cfDNA in human blood [43,44]. The cfDNA is composed of both genomic DNA (gDNA) and mitochondrial DNA (mtDNA) [45]. The concentration of cfDNA has been assessed previously by quantitative PCR (such as TaqMan and SYBR Green) or by different fluorescence-based methods (such as, ultraviolet (UV) spectrometry and PicoGreen staining) [46].

Based on the above discussion, increased oxidative stress, which might result in enhancing inflammatory status and result in cell damage can therefore proposed to rise in circulation of cfDNA. Therefore, various metabolic diseases also can have high chances of high cfDNA level in circulation according to hypothesis of related cfDNA with oxidative stress. The significant disorders might be associated with cfDNA are mertabolic diseases high oxidative stress, for example, obesity and diabetes [47-49]. Studies are required in future to look into the effect of severity of metabolomics stress and oxidative stress on cfDNA [50].

\section{Conclusion}

Looking at the cited literature, we hypothesized to the conclusion that there is a correlation between the obesity and elevated cfDNA levels. This correlation based on free radicals and oxidative stress hypothesis of cellular molecules damage and cell injury which in turn leads to a disorder in the whole body, but it still needs to more study and investigation.

\section{References}

1. Garrow JS (1988) Obesity and related diseases. Churchill Livingstone, UK. Pp. 1-16.

2. http://www.who.int/topics/obesity/en/

3. Kumanyika SK, Obarzanek E, Stettler N, Bell R, Field AE, et al. (2008) Population-based prevention of obesity: the need for comprehensive promotion of healthful eating, physical activity, and energy balance: a scientific statement from American Heart Association Council on Epidemiology and Prevention. Circulation 118(4): 428-464.

4. http://www.ama-assn.org/ama/pub/news/news/2013/2013-06-18new-ama-policies-annual-meeting.page.

5. Peeters A, Barendregt JJ, Willekens F, Mackenbach JP, Al Mamun A, et al. (2003) Obesity in adulthood and its consequences for life expectancy: a life-table analysis. Ann intern med138(1): 24-32.

6. Berghöfer A, Pischon T, Reinhold T, Apovian CM, Sharma AM, et al. (2008) Obesity prevalence from a European perspective: a systematic review. BMC public health 8(1): 200.

7. Kelly T, Yang W, Chen CS, Reynolds K, He J (2008) Global burden of obesity in 2005 and projections to 2030. Int J obes 32(9): 1431-1437.
8. Wang Y, Beydoun MA, Liang L, Caballero B, Kumanyika SK (2008) Will all Americans become overweight or obese? Estimating the progression and cost of the US obesity epidemic. Obesity 16(10): 2323-2330.

9. Ng M, Fleming T, Robinson M, Thomson B, Graetz N, et al. (2014) Global, regional, and national prevalence of overweight and obesity in children and adults during 1980-2013: a systematic analysis for the Global Burden of Disease Study 2013. The lancet 384(9945): 766-781.

10. Kant AK, Graubard BI (2006) Secular trends in patterns of selfreported food consumption of adult Americans: NHANES 1971-1975 to NHANES 1999-2002. Am J Clin Nutr 84(5): 1215-1223.

11. Prentice AM, Jebb SA (1995) Obesity in Britain: gluttony or sloth? BMJ 311(7002): 437-439.

12. Dietz WH, Gortmaker SL (1985) Do we fatten our children at the television set? Obesity and television viewing in children and adolescents. Pediatrics 75(5): 807-812.

13. Andreasen CH, Andersen G (2009) Gene-environment interactions and obesity-further aspects of genomewide association studies. Nutrition 25(10): 998-1003.

14. Tiret L, Poirier O, Nicaud V, Barbaux S, Herrmann SM, et al (2002) Heterogeneity of linkage disequilibrium in human genes has implications for association studies of common diseases. Hum Mol Genet 11(4): 419-429.

15. Rao UM, Haque M, Baig AA (2011) Insulin stimulative and antioxidative effects of Persea americana fruit extract on streptozotocin induced hyperglycemic rats. Insulin 4(1).

16. Atif AB, Emilia A, Aliya S, Aamenah M, Zahri MK, et al. (2014). Genetics of Obesity: The Rise of Neutrigenetics, Asian Adipocytes and Strategy Towards Preventing Obesity. WJPR, 3(9): 94-101.

17. Umar Faruk Abdullahi, Rochman Naim, Wan Rohani Wan Taib, Ahmadu Saleh, Anas Muazu, et al. (2015) Loop-mediated isothermal amplification (LAMP), an innovation in gene amplification: bridging the gap in molecular diagnostics; a review. Indian Journal of Science and Technology, 8(17): 1-12.

18. Alberti KG, Zimmet PZ (1998) Definition, diagnosis and classification of diabetes mellitus and its complications. Part 1: Diagnosis and classification of diabetes mellitus provisional report of a WHO consultation. Diabet Med 15: 539-553.

19. Xu H, Barnes GT, Yang Q Tan G, Yang D, et al. (2003) Chronic inflammation in fat plays a crucial role in the development of obesityrelated insulin resistance. J Clin Invest 112(12):1821-1830.

20. Cristancho AG, Lazar MA (2011) Forming functional fat: a growing understanding of adipocyte differentiation. Nature reviews Molecular cell biology 12(11): 722-734.

21. Fernández-Sánchez A, Madrigal-Santillán E, Bautista M, Esquivel-Soto J, Morales-González Á, et al. (2011) Inflammation, oxidative stress, and obesity. Int J Mol Sci 12(5): 3117-3132.

22. Hensley K, Robinson KA, Gabbita SP, Salsman S, Floyd RA (2000) Reactive oxygen species, cell signaling, and cell injury. Free Radic Biol Med 28(10): 1456-1462.

23. Redman CW, Sargent IL (2003) Pre-eclampsia, the placenta and the maternal systemic inflammatory response-a review. Placenta 24: S2127.

24. Maira S, Hareem A, Holifaa A, Saif UK, Al-Hatamleh MAI, et al. (2017) Role of Tocopherols in Treatment of Depression related Alzheimer's Disease. Prim Health Care 7(279): 2167-1079.

25. Sies H (2015) Oxidative stress: a concept in redox biology and medicine. Redox Biol 4: 180-183. 
26. Rohin MAK, Abd Hadi N, Naim R, Atif AB, Mahmud K (2014) Study on Antioxidant Capacity And Anticancer Activity Of Bismillah Leaf (Vernonia Amygdalina). World Journal of Pharmaceutical Research 3(6): 14-29.

27. Al-Hatamleh MAI, Atif AB, Nordin S, Ilyas MN, Saif UK, et al. (2017) Molecular Modulation of Stress Induced to Abnormal Haematological Indices in Medical Students, Malaysian Perspective. Pakistan J Biol Sci 20(10): 478-488.

28. Rasheed N, Ahmad A, Al-Sheeha M, Alghasham A, Palit G (2011) Neuroprotective and anti-stress effect of A68930 in acute and chronic unpredictable stress model in rats. Neuroscience letters 504(2): 151155.

29. Sorce S, Krause KH (2009) NOX enzymes in the central nervous system: from signaling to disease. Antioxid Redox signal 11(10): 2481-2504.

30. Naureen S, Irfan M, Zin T, Tariq R, Baig AA, et al. (2014) Cortisol and Obesity; a Stress Related Insight: Obesity and Cortisol. CreateSpace Independent Publishing Platform, USA.

31. McCord JM (1985) Oxygen-derived free radicals in postischemic tissue injury. N Engl J Med 312(3): 159-163.

32. Dröge W (2002) Free radicals in the physiological control of cell function. Physiological reviews 82(1): 47-95.

33. Krause K (2007) Aging: A revisited theory based on free radicals generated by NOX family NADPH oxidases. Exp Gerontol 42(4): 256262.

34. Bedard K, Krause KH (2007) The NOX family of ROS-generating NADPH oxidases: physiology and pathophysiology. Physiol Rev 87(1): 245-313.

35. Hordijk PL (2006) Regulation of NADPH oxidases. Circ Res 98(4): 453462.

36. Mandel $P$ (1948) Les acides nucleiques du plasma sanguin chez l'homme. C R Seances Soc Biol Fil 142(3-4): 241-243.

37. Sorenson GD, Pribish DM, Valone FH, Memoli VA, Bzik DJ, et al. (1994) Soluble normal and mutated DNA sequences from single-copy genes in human blood. Cancer Epidemiol Biomarkers Prev 3(1): 67-71.

38. Vasioukhin V, Anker P, Maurice P, Lyautey J, Lederrey C, et al. (1994) Point mutations of the N-ras gene in the blood plasma DNA of patients with myelodysplastic syndrome or acute myelogenous leukaemia. $\mathrm{Br}]$ Haematol 86(4): 774-779.
39. Jahr S, Hentze H, Englisch S, Hardt D, Fackelmayer FO, et al. (2001) DNA fragments in the blood plasma of cancer patients: quantitations and evidence for their origin from apoptotic and necrotic cells. Cancer Res 61(4): 1659-1665.

40. Stroun M, Anker P, Lyautey J, Lederrey C, Maurice PA (1987) Isolation and characterization of DNA from the plasma of cancer patients. Eur J Cancer Clin Oncol 23(6): 707-712.

41. Sorenson G (1997) Communication at the XXVth anniversary meeting of the international society for oncodevelopmental biology and medicine. Montreux, Switzerland.

42. Lui YY, Chik KW, Chiu RW, Ho CY, Lam CW, et al. (2002) Predominant hematopoietic origin of cell-free DNA in plasma and serum after sexmismatched bone marrow transplantation. Clin Chem 48(3): 421-427.

43. Rogers JC, Boldt D, Kornfeld S, Skinner SA, Valeri CR (1972) Excretion of deoxyribonucleic acid by lymphocytes stimulated with phytohemagglutinin or antigen. Proc Natl Acad Sci 69(7): 1685-1689.

44. Suzuki N, Kamataki A, Yamaki J, Homma Y (2008) Characterization of circulating DNA in healthy human plasma. Clinica Chimica Acta 387(1): 55-58.

45. Stroun M, Maurice P, Vasioukhin V, Lyautey J, Lederrey C, et al. (2000) The origin and mechanism of circulating DNA. Annals of the New York Academy of Sciences 906(1): 161-168.

46. Mehra N, Penning M, Maas J, van Daal N, Giles RH, et al. (2007) Circulating mitochondrial nucleic acids have prognostic value for survival in patients with advanced prostate cancer. Clin Cancer Res 13(2): 421-426.

47. Schwarzenbach H, Hoon DS, Pantel K (2011) Cell-free nucleic acids as biomarkers in cancer patients. Nat Rev Cancer 11(6): 426-437.

48. Baig AA, Khan SA, Younis Hussein Abdullah U, Simbak N (2014) Genetics of Obesity: The Rise of Neutrogenetics, Asian Adipocytes and Strategy Towards Preventing Obesity. World Journal of Pharmaceutical Research 3(9): 94-101.

49. Zahri MK, Emilia A, Rawi RI, Taib WR, Sani AI, et al. (2016) Contribution of the Pro12Ala polymorphism of peroxisome proliferator-activated receptor $\gamma 2$ gene in relation to obesity. Meta Gene 10: 39-44.

50. Marini M, Sasongko TH, Watihayati MS, et al. (2012) Allele-specific PCR for a cost-effective \& time-efficient diagnostic screening of spinal muscular atrophy. The Indian Journal of Medical Research 135(1): 3135.

Your next submission with Juniper Publishers
will reach you the below assets
- Quality Editorial service
- Swift Peer Review
- Reprints availability
- E-prints Service
- Manuscript Podcast for convenient understanding
- Global attainment for your research
- Manuscript accessibility in different formats
( Pdf, E-pub, Full Text, Audio)
- Unceasing customer service
Track the below URL for one-step submission
https://juniperpublishers.com/online-submission.php

